\title{
WHOLE GENOME EXPRESSION IN NEWBORN MOUSE BRAIN TISSUE AFTER HYPOXIA AND REOXYGENATION
}

E.J. Wollen ${ }^{1}$, M.S. Wright ${ }^{1}$, C.-C. Gunther ${ }^{2}$, M. Bik-Multanowski ${ }^{3}$, A. Madetko-Talowska ${ }^{3}$, Y. Sejersted ${ }^{1}$, P. Kwinta $^{3}$, J.J. Pietrzyk ${ }^{3}$, O.D. Saugstad ${ }^{1}$

${ }^{1}$ Department of Pediatric Research, Oslo University Hospital HF, Rikshospitalet, ${ }^{2}$ Norwegian Computer

Center, Oslo, Norway, ${ }^{3}$ Departments of Pediatric and Medical Genetics, Jagiellonian University Medical College, Krakow, Poland

Supplementary oxygen during resuscitation can be harmful to the immature brain and lead to both acute and long-term morbidity. The aim was to study whole genome expression alterations induced by supplementary oxygen in the brain in a newborn mouse model of hypoxia and reoxygenation.

C57BL/6 mice $(\mathrm{n}=41)$ postnatal day 7 were randomized to hypoxia $\left(8 \% \mathrm{O} 2,36 \pm 0.5 \mathrm{C}^{\circ}\right)$ for 120 min and reoxygenation for $30 \mathrm{~min}$ in $21 \%(\mathrm{H} 21, \mathrm{n}=9), 40 \%(\mathrm{H} 40, \mathrm{n}=10), 60 \%(\mathrm{H} 60, \mathrm{n}=11)$ or $100 \%(\mathrm{H} 100, \mathrm{n}=11)$ $\mathrm{O} 2$ for $30 \mathrm{~min}$. After $150 \mathrm{~min}$ recovery in room air, mice were sacrificed and brain tissue harvested. The control group $(\mathrm{C} 21, \mathrm{n}=9)$ was exposed to $21 \% \mathrm{O} 2$ for 300 min.Qiagen RNeasy kit was used for mRNA extraction. GeneChip Mouse Gene ST 1.0 Arrays (Affymetrix) were used to analyze whole genome expression. Statistical analyses were performed by using BAMarray Software. GSEA was used for pathway analyses.

458 genes were significantly differentially expressed in brain tissue in the comparison between $\mathrm{C} 21$ and the 4 hypoxia groups (H21: 32, H40: 7, H60: 117, H100: 302). 91.5\% of the genes are represented in H60 and H100 groups. 40 genes are overlapping between group H60 and H100. Oxidative phosphorylation is one pathway that is significantly down regulated (FDR q-value $<0.10$ ) for both H60 and H100.

$91.5 \%$ of the genes differentially expressed are represented in the groups resuscitated with either 60 or $100 \% \mathrm{O}_{2}$. Hypoxia followed by hyperoxia induces the down regulation of oxidative phosphorylation in the current model. 